\title{
Quality Improvement of Public Services in Surabaya Radio Frequency Spectrum Monitoring Office with Integration of Service Quality, Important Performance Analysis and House of Quality
}

\author{
Henry Pribadi and Mokhamad Suef \\ Department of Technology Management, Institut Teknologi Sepuluh Nopember, Surabaya \\ e-mail: henrypribadi6000@gmail.com,mokhsuef@gmail.com
}

\begin{abstract}
Abstrak-The purpose of frequency spectrum management is to be effective, efficient, and free interferrence in frequency usage. As a Ministry Technical Unit, Balmon Surabaya has the task to supervise and controll the frequency usage in East Java. In carrying out their duties, there are some user's complaints about Balmon Surabaya services. Therefore it is necesary to improve the quality of service and to know what service factors affecting the customers satisfaction. Objective of this research is to determine the quality of services and technical response that should be done in accordance with expectations of customers. The services as the object of the research are Radio Station License Distribution, Payment Notification Letter Distribution, and Interferrence of Frequency Report Handling. Measurement of the service is performed using Servqual methode while determining the variable to be improved use Important Performance Analysis. Then, Quality Function Deployment is utilized to develop the technical response influencing the service quality. The result shows that the highest gap is providing the free-toll telephone line, the 2 nd is mentioning the data/references in giving the informations, and the 3rd is distributing the Payment Notification Letter before the due date. The Importance- Performance Analysis shows that there are 3 variabels in Quadrant I, distributing the Payment Notification Letter before the due date, mentioning the data/refferences in giving the informations, and providing of free-toll telephone line. QFD reveals that there are 3 Technical Responses with highest value of Important Rating of ie., the printing the Payment Notification Letter 2 months before the due date; confirming the letter receipt by the user, and proposing the toll-free number.
\end{abstract}

Keywords-Important Performance Analysis, Monitoring Office, Service Quality, Quality Function Deployment.

\section{INTRODUCTION}

$\mathrm{O}$ $\mathrm{NE}$ of the Indonesia's Reform Agenda is the implementation of Good Governance. To achieve that, the government has published laws governing the government administrators to provide good services to the public where the standard of the service could be measured by assessing the costumers' satisfaction after using the produk and costumers' expectation before using the product [1]. As a public service provider, Balmon Surabaya has the duties to supervise and to control the radio frequency spectrum usage in East Jawa. The Balmon Surabaya public services such as Radio Station Lisence (RSL) Distribution, Payment Notification Letter (PNL) Distribution, and Frequency Interference Handling.

The frequency usage in East Jawa reaches more than 100.000 channels with more than 1.000 users. In order to improve the quality service of Balmon Surabaya, this study was conducted to measure service quality using Servqual method, to define the priority of variable that need to be improved by using IPA method, and to deternine the technical response as the variable improvement step by using QFD method.

\section{LITERATURE REVIEW}

\section{A. Balmon Surabaya Services}

According to the report of Balmon Surabaya [2] the services of Balmon Surabaya on frequency users are listed below;

a) Station Radio Lisence (SRL) Distribution

b) Payment Notification Letter (PNL) Distribution

c) Frequency Interference Handling.

These services are obtained by the user after the user gets the radio frequency spectrum usage lisence.

The benefits for the users who get the services are:

a) Protection from frequency interference.

b) Appropriate frequency usage according to the parameter.

c) Avoid punishment for violating frequency usage.

1) Service Quality (Servqual).

The service quality measurement method was first introduced by [3]. The measurement is determined by calculating the gap between the perception perceived by the costumer after enjoying the service and the costumer's expectation before enjoying the service or in the formula:

SERVQUAL $=$ Perception - Expectation

According to Parasuraman, et al.(1988), there are 5 (five) gap models in Servqual, such as:

a. Gap 1. The Gap between customer expectation regarding management thought or opinion about costumer expectation. 


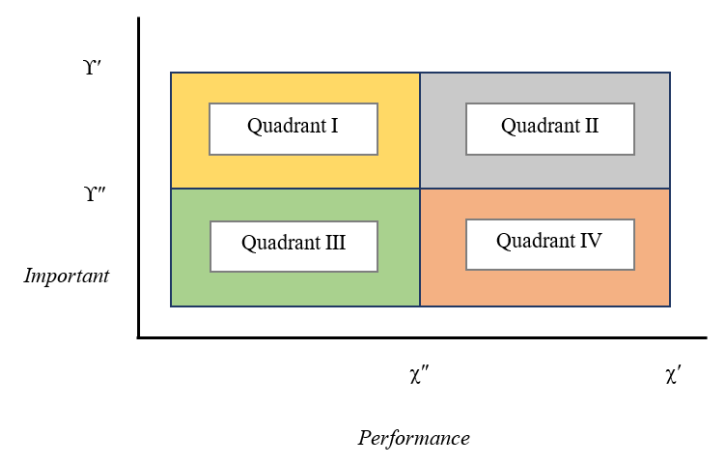

Figure 1. Mapping of the conformity value

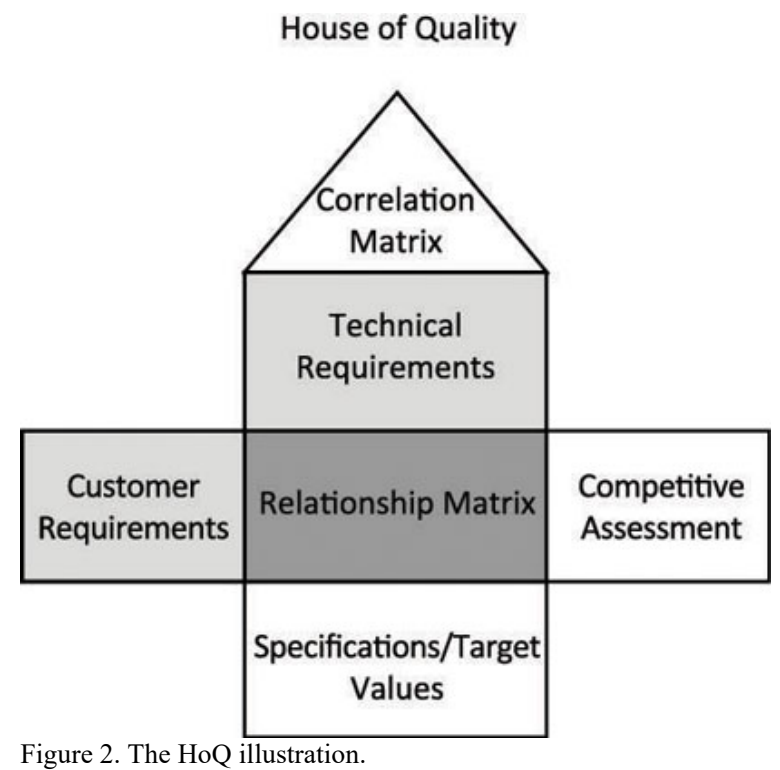

b. Gap 2. The Gap between the management thought or opinion regarding costumer's expectation with the service quality specification and design.

c. Gap 3. The Gap between specification or service quality standards and service delivery to the costumers.

d. Gap 4. The Gap between service delivery to costumer with the promised or conveyed quality service by the company or service provider through external media.

e. Gap 5. The Gap between costumer's expectation and perception lays on the costumer's posisition and is caused by the appearance of 1 (one) or more than 1 gap.

There are 5 (five) dimensions used for measuring the service quality in the Servqual method, such as:

a. Tangibles are related to the used physical evidence of the provider, for instance: cosntructions, buildings, equipments, facilities, employee performace, and other infrastructures.

b. Reliability is related to the ability of providers to fulfill the promised service which is offered with a high level of accuracy.

c. Responsiveness is related to the willingness or unwillingness of the organization to provide quick services to customers

d. Assurance, is a combination of competence, credibility, and security dimensions, related to the level of knowledge, ability, and manner of organization employees who provide confidence and trust in customers.

e. Emphaty is a combination of access, communication and understanding of the customer, related to the individual concern and attention of the organization to the customer.

2) Important Performance Analysis (IPS)

Important Performance Analysis (IPA) is a procedure to show the relative importance of various variables on the performance of an organization or company [4], IPA is a simple and effective technique that is able to help business player to identify the priorities for improving service variables and quality-based marketing strategies. IPA is applied to analyze 2 (two) dimensions of service variables, namely: the level of performance (satisfaction or perception) of customers and the level of importance of variables for customers [5], The IPA is calculated by observing the level of conformity, where the Conformity Level is a comparison between the Performance Level on the variable with the Importance Level of the corresponding variable. The conformity value of the IPA analysis is shown in Figure 1, the form of a Cartesian diagram with the $\mathrm{x}$-axis showing the level of performance and the y-axis indicating the level of importance.

In the Kartesian Diagram, there are 4 (four) quadrants that present:

a) Quadrant I

The variables included in Quadrant I are the variables that are the top priority for improvement due to low performance and high customer importance [6]

b) Quadrant II

The variables included in Quadrant II are the variables that need to be considered because of both the high importance and high perception [6].

c) Quadrant III

The variables included in Quadrant III are the variables with low interest and perception so that it is a minor weakness and no need additional effort to improve [7].

d) Quadrant IV

Variables included in Quadrant IV are the variables with high perception but low of importance, so the management could ignore these variables and existing resources can be used to improve other variables [7].

3) Quality Function Deployment (QFD)

The shift of the government agency services towards a public satisfaction as one of the reform agendas, clarify that public satisfaction is one of the important indicators in assessing the performance of government agencies. Measuring the level of public satisfaction that is able to show the level of satisfaction but is not followed by service improvement steps is useless. For this reason, this study will use the Quality Function Deployment (QFD) method, which is a product improvement method with a structured approach to interpret customer needs into a specific product plan with the aim of producing products that can meet the needs [8]. Akao call QFD as 'hin shitsu kino ten kai', which means:

a) Hin shitsu means quality or variable or feature 
2nd International Conference on Industrial and System Engineering (IConISE) and

7 th Annual Conference on Industrial and System Engineering (ACISE) 2020

July $22^{\text {nd }}-23^{\text {rd }} 2020$, Surabaya, Indonesia

Table 1.

Distribution of respondent

\begin{tabular}{ccccc}
\hline \hline $\begin{array}{c}\text { Costumer } \\
\text { Type }\end{array}$ & City & Total Customer & Total Respondent & Remarks \\
\hline Penyiaran FM & Surabaya & 29 & 29 & $100 \%$ \\
& Malang & 14 & 14 & $100 \%$ \\
& Kediri & 7 & 7 & $100 \%$ \\
Subtotal & & 50 & 50 & Proporsional \\
Consession & Surabaya & 295 & 70 & Proporsional \\
& Malang & 58 & 6 & Proporsional \\
\hline Subtotal & Kediri & 26 & 3 & $\mathbf{7 9}$ \\
TOTAL & & $\mathbf{4 2 9}$ & & \\
\hline \hline
\end{tabular}

Table 2.

Validity and reliability testing results.

\begin{tabular}{cccc}
\hline \hline No & Data Type & Total Variable & Cronbach alpha \\
\hline 1 & Expectation Data & 16 & 0.935 \\
2 & Perception Data & 16 & 0.935 \\
3 & Interest Data & 16 & 0.900 \\
\hline \hline
\end{tabular}

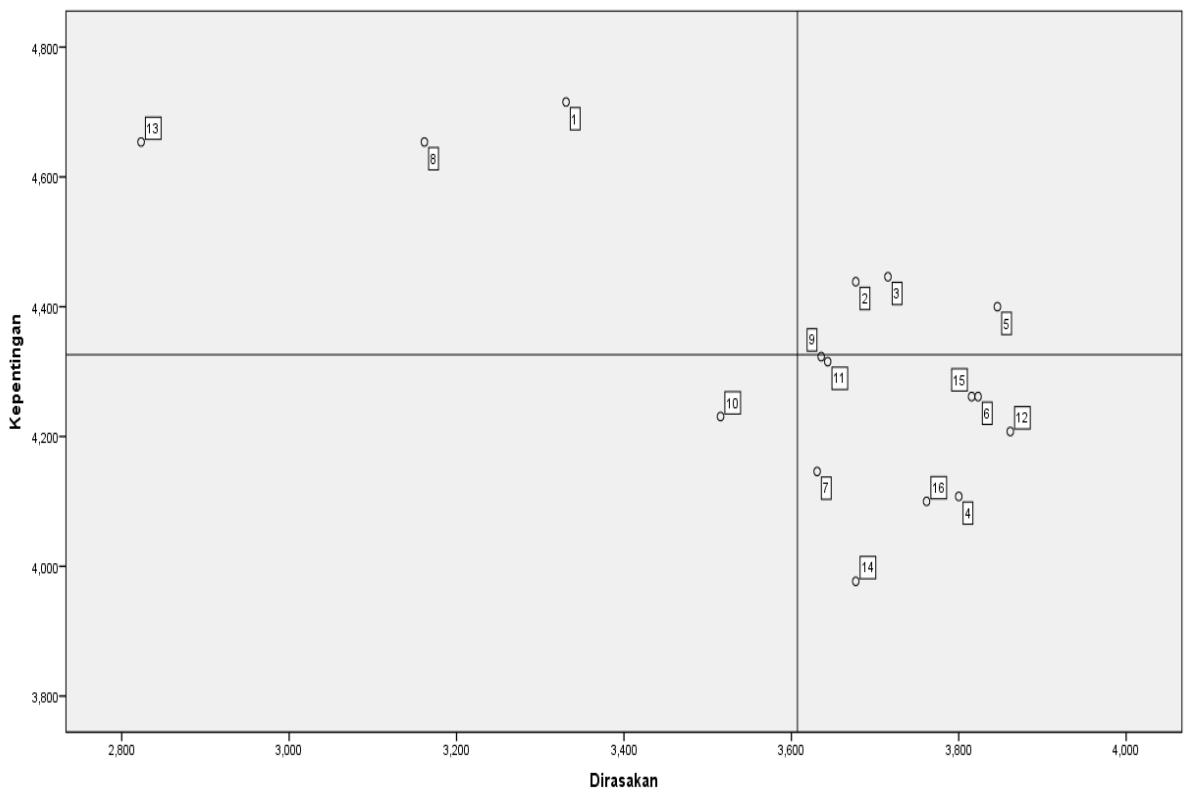

Figure 3. Plot the importanve level and the performance level of the data.

b) Kino means function or mechanization

c) Ten kai means development, establishment, diffusion or evolution

One aspect that determines the success of an organization in implementing QFD is the organization's ability to interpret customer needs. The customer needs is also called as the Voice of Customer ( $\mathrm{VoC})$ [9].

The principal tool used in QFD is the House of Quality (HOQ). HOQ is able to show the relationship between consumer needs and is interpreted in technical variables and in the form of a matrix or "quality table" [10]. HoQ is useful in product planning that is used to describe customer needs, technical measures, target values, and competitive analyzes. HOQ consists of several matrices that are interconnected one with the others [10], So HoQ is a matrix-shaped tool used to explain customer needs and expectations as well as methods to meet the customer needs. By using the matrix as the main tool in the formulation of QFD, the relationship between "WHAT" and "HOW" can be described clearly and unambiguously [10]. The HoQ illustration can be seen in Figure 2.

\section{B. Research Method}

The research was carried out in some stages including: Data collection, making questionnaires, determining survey samples, initial surveys, validity and reliability testing, distributing and collecting questionnaire data; data processing and analysis using Serqual, IPA, and HoQ; and Finally, the formulation of a recommended action. 
2nd International Conference on Industrial and System Engineering (IConISE) and

7th Annual Conference on Industrial and System Engineering (ACISE) 2020

July $22^{\text {nd }}-23^{\text {rd }} 2020$, Surabaya, Indonesia

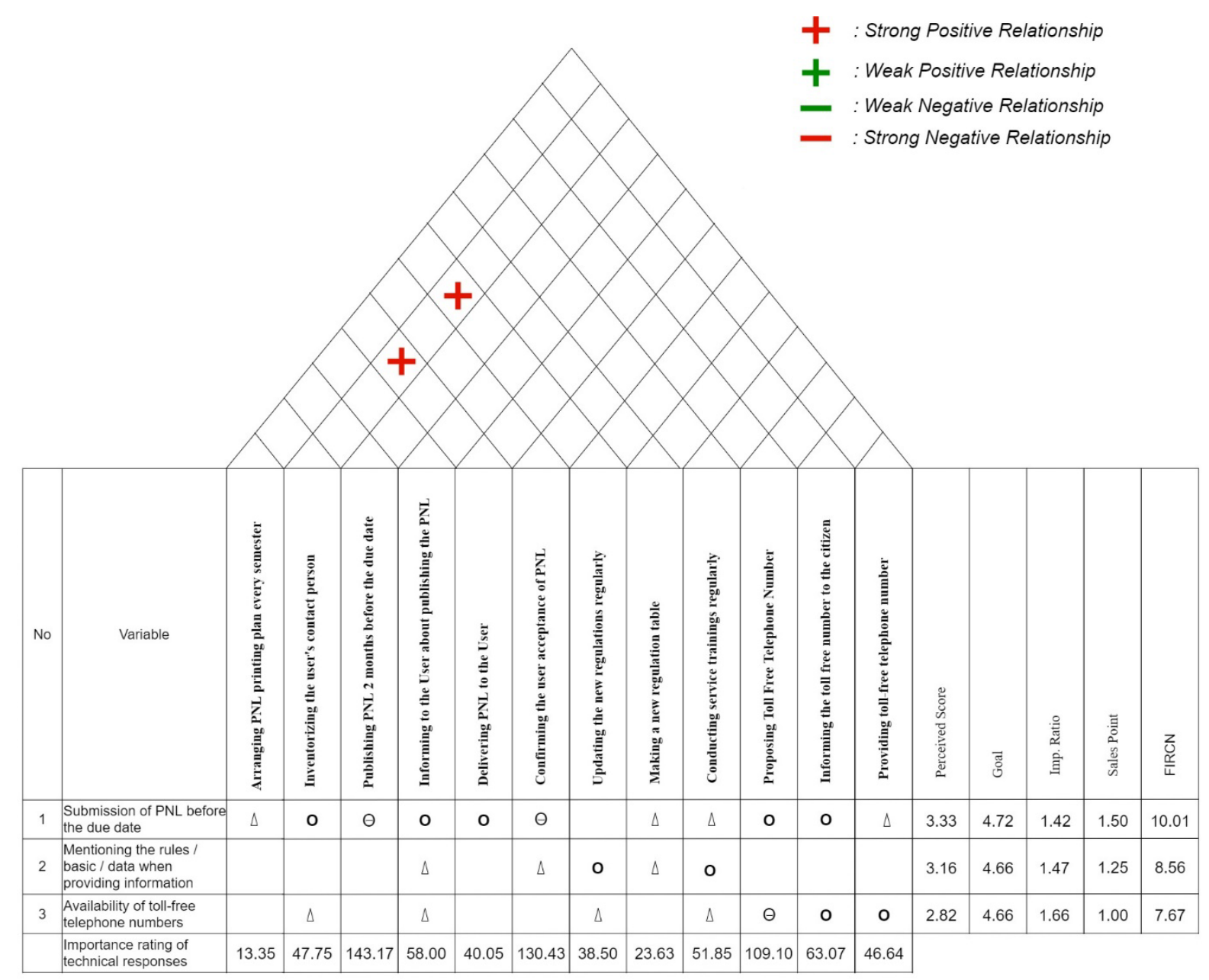

Figure 4. Technical Responses for the Three importance variables.

Table 3.

Technical responses for the three variables

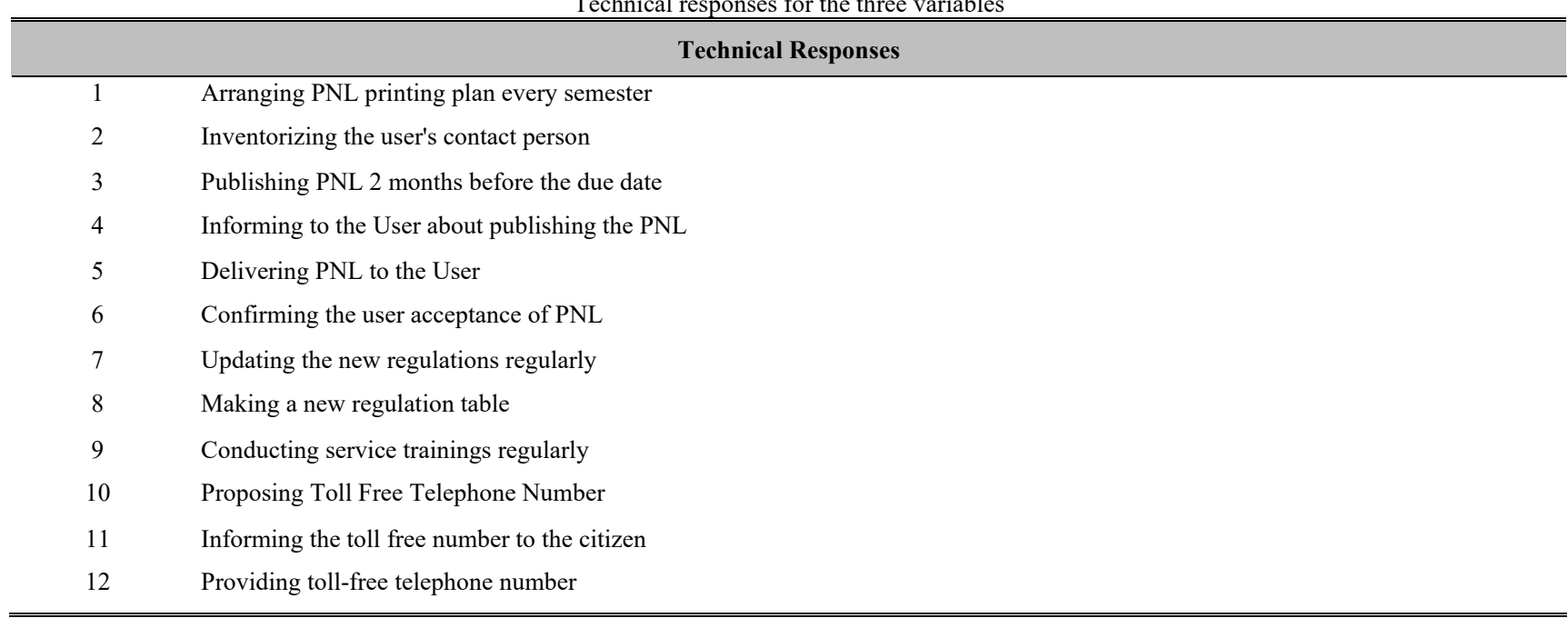

\section{RESULT}

Research respondents were The Balmon users in Surabaya, Malang, and Kediri in total of 429 (four hundred and twenty nine) users. By using the Slovin formula to determine samples, minimum number of samples is 129 (one hundred twenty-nine) samples. By anticipating return rate of a questionnaire, 300 (three hundred) questionnaire sheets are distributed and 130 (one hundred thirty) questionnaires are returned. 
2nd International Conference on Industrial and System Engineering (IConISE) and

7 th Annual Conference on Industrial and System Engineering (ACISE) 2020

July $22^{\text {nd }}-23^{\text {rd }} 2020$, Surabaya, Indonesia

\section{A. Validity and Reliability Testing.}

By using SPSS 25, the obtained results of the validity and reliability test of the questionnaire are valid and reliable. The validity and reliability test results are seen in the Table 2From the test results, it is known that the questionnaire data is valid and reliable.

\section{B. Service Quality}

By using the Servqual method, there are 5 (five) highest gap between customer perceptions and expectations, such as:

a) Availability of toll-free telephone numbers, average gap: 1.46.

b) Mentioning the rules / basic / data when providing information, average gap: $-1,16$.

c) Submission of PNL before the due date, average gap: 1.11 .

d) Delivery of SRL on time, average gap: -0.74 .

e) Interference Report are handled well, average gap: -0.68 . Importance-Performance Analysis.

By using the Importance-Performance Analysis, which is Performance is represented by the Perceived Quality and Importance is represented by the Expected Quality, we plot all the data into Figure 3.

From the diagram above it is shown that:

1) Quadrant I.

The variables included in Quadrant I are:

a. Submission of PNL before the due

b. Mentioning the rules / basic / data when providing information

c. Availability of toll free telephone numbers

2) Quadrant II.

The variables included in Quadrant II are:

a. On time SRL Distribution(R-2)

b. Interference Reports are Handled Well(R-3)

c. Responsiveness in responding to reports (RS-1)

3) Quadrant III.

There are 1 (one) variables included in Quadrant III, namely: Proactive in contacting customers (E-1).

4) Quadrant IV.

The variables included in Quadrant IV are:

a. Accuracy of the operating hours (R-4)

b. Simplicity in obtaining information (RS-2)

c. Availability of alternative communication media beside telephone (RS-3)

d. Firmed Information and not diverse (A-2)

e. Ease of contacting officers (E-2)

f. Ease of reaching Graha Postel (T-1)

g. Availability of brochures / service pamphlets (T-3)

h. Complete and standard working tools (T-4)

i. The officer wears a uniform or official identity (T-5)

From the IPA analysis it is known that the variables included in Quadrant I are:

1. Submission of PNL before the due date

2. Mentioning the rules / basic / data when providing information.

3. Availability of toll-free telephone numbers.

These variables then, are analyzed further using QFD.

Result of the analysis are given in the HoQ depicted in

Figure 4.
From the discussions with management, it was agreed that there were 12 (twelve) Technical Responses arranged to improve the 3 (three) variables in Quadrant I. The 12 technical responses are mentioned in the Table 3.

Sales point and goal values are the result of the discussions with management, and are used to calculate the Final Important Rating for Customer Needs (FIRCN). From the FIRCN calculation results, the FIRCN values are: Submission of PNL before due date is 10.01; Mentioning the rules / basic / data when providing information is 8.56; and Availability of toll-free telephone numbers is 7.67.

By adding up the multiplication results between FIRCN and the quality of the relationship between variables and technical responses, the Important Rating of Technical Response (IRTR) values are obtained. The highest IRTR value is the Technical Response that will be used in correcting variables.

From the results of the calculation of IRTR, it is obtained that: Printing PNL 2 months before the due date is the highest Technical Response with IRTR 143.17; Confirming receipt of PNL by the user is the second technical response with IRTR 130.43; and Proposing the creation of a toll-free number is the third technical response with IRTR 109.1.

\section{REFERENCES}

[1]. F Tjiptono 2016 Service, Quality, \& Satisfaction, Edisi 4, Yogyakarta.: C.V. Andi Offset.

[2]. Balai Monitoring Surabaya 2015 Laporan Tahunan 2014 Balai Monitor Kelas II Surabaya. internal, Surabaya.

[3]. Parasuraman and A. Zeithaml 2004 Service Quality, Cambridge: Marketing Science Institute.

[4]. T. Wijaya 2011 Manajemen Kualitas Jasa, Jakarta: Permata Puri Media.

[5]. Huang Y-K, Fan W-S, Tsai M-C and Ho Y-H 2015 Using Importance-Performance Analysis in Evaluating Taiwan Blog eService Quality. Journal of Economics, Business and Management. EJournal Publishing 3(3):338-45. doi.org/10.7763/joebm.2015.v3.206.

[6]. K. Kotler 2006 Marketing Management, New Jersey: Pearson International Edition.

[7]. L. Parasuraman and A Zeithmal V 1998 SERVQUAL: A MulitpleItem Scale for Measuring Consumer Perceptions of Service Quality. Jurnal Retailing 64(1) p 55 - 69.

[8]. Y. Akao 1991 Quality Function Deployment: Integrating Costumer Requirement into Product Design, Oregon, USA: Productivity Press.

[9]. Chan L-K and Wu M-L 2002 Quality function deployment: A literature review. Eur. J. Oper. Res. Elsevier BV 143(3):463-97. doi.org/10.1016/s0377-2217(02)00178-9.

[10]. L. Cohen 2005 Quality Function Deployment: How to Make QFD Work for You, Singapore: Addison-Wesley. 